\title{
Defluoridation of South Tunisian Brackish Water by Alum Coagulation/Flocculation: A Preliminary Work
}

\author{
Khaoula Missaoui, Wided Bouguerra, Chiraz Hannachi, Nabiha Gannouni, \\ Béchir Hamrouni \\ Université de Tunis El Manar, Faculté des sciences de Tunis, UR11ES17 Traitement et Dessalement des Eaux, \\ 2092, Tunis, Tunisie \\ E-mail: misskawla13@gmail.com
}

\begin{abstract}
Fluoride removal from aqueous solution was investigated using the chemical coagulation-flocculation by alum in reason of the efficiency and the simplicity of the process. Preliminary experiments were carried out to study the effect of some operating parameters such as: $\mathrm{pH}$, initial fluoride concentration, coagulant dose, adjuvant coagulation dose, flocculent dose and settling time. Obtained experimental results showed that the treatment of fluoride by alum coagulation causes acidification of the solution. The effect of the initial $\mathrm{pH}$ solution on fluoride removal is negligible. Experimental results proved that coagulation process is effective in waters with low or medium levels of fluoride. Defluoridation rate was seen to increase with increasing coagulant and adjuvant coagulation doses. Optimal flocculent dose and optimal settling time were found $4.2 \mathrm{mg} \mathrm{L}^{-1}$ of $\mathrm{FABI}$ and 60 min respectively. Subsequently, experimental design methodology using two-level full factorial design was applied to optimize the defluoridation by coagulation-flocculation. Therefore, four operating parameters which are supposed to affect the removal efficiency were chosen: initial fluoride concentration, coagulant dose, coagulation adjuvant dose and settling time. From the statistical analysis, it is inferred that the four studied parameters have an influence on the fluoride removal. In fact, initial fluoride concentration has a positive effect unlike coagulant dose, coagulation adjuvant dose and settling time. Experiment tests were performed to evaluate the efficiency of coagulation-flocculation process for south Tunisian brackish water with high fluoride concentration. The obtained results showed that fluoride removal reached $59 \%$.
\end{abstract}

Keywords: Defluoridation; brackish Tunisian water; coagulation-flocculation; Alum; full factorial design.

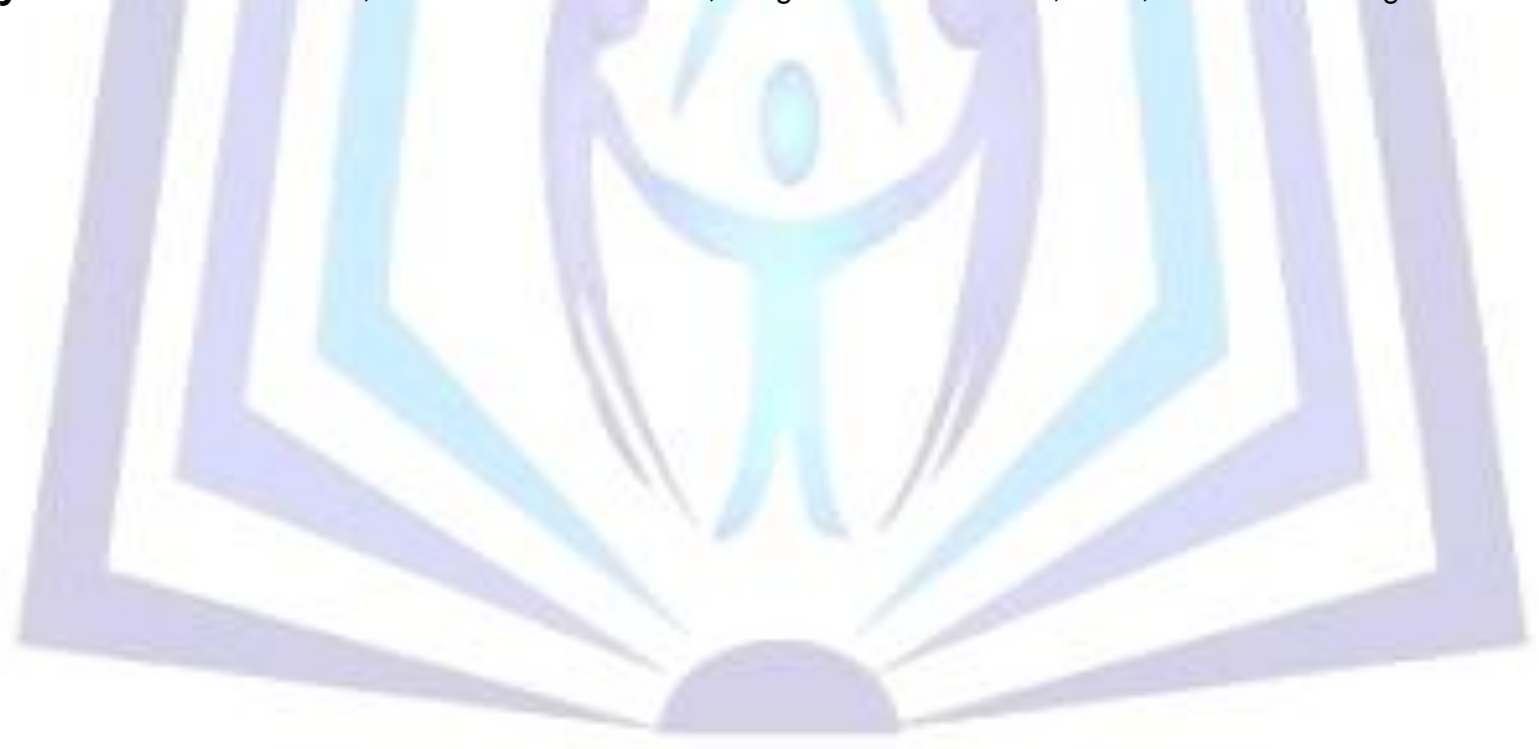

\section{Council for Innovative Research}

Peer Review Research Publishing System

Journal: Journal of Advances in Chemistry

Vol. 5, No. 3

editor@cirworld.com

www.cirworld.com, member.cirworld.com 


\section{Introduction}

The fluoride occurs mainly as sellaite $\mathrm{MgF}_{2}$, fluorspar $\mathrm{CaF}_{2}$, cryolite $\left(\mathrm{Na}_{3} \mathrm{AlF}_{6}\right)$, and fluorapatite $\left.\left(3 \mathrm{Ca}_{3}(\mathrm{PO})_{2}\right)_{2} \cdot \mathrm{Ca}(\mathrm{F}, \mathrm{Cl})_{2}\right)$ $[1,2]$. Fluorspar is found in sedimentary rocks while cryolite is found in igneous rocks. These fluoride minerals are nearly insoluble in water. Hence fluorides will be present in groundwater only when conditions favor their dissolution or high fluoride containing effluents are discharged to the water bodies from industries. Fluoride removal receives much attention due to the dental and skeletal fluorosis caused by the excessive intake of fluoride [3].

In the south Tunisian brackish water, the range level of fluoride ions is situated between 1.5 and $2.5 \mathrm{mg} \mathrm{L}^{-1}$. However, in the region of Gafsa fluoride content greater than $2.5 \mathrm{mg} \mathrm{L}^{-1}$ are encountered [4].

The World Health Organization (WHO) fixed the maximum fluoride concentration in drinking water as $1.5 \mathrm{mg} \mathrm{L}^{-1}$. In excess of 1.5-2.0 mg L $\mathrm{L}^{-1}$ fluoride is known to cause permanent gray or black mottling of teeth enamel and the long-term intake of 3-10 $\mathrm{mg} \mathrm{L}^{-1}$ may result in abnormal bone growth in both humans and animals. Invertebrates and fish in fresh water are also very sensitive to fluoride toxicity [5]. Many methods have been developed to remove excessive fluoride from drinking water. These methods can be categorized into four categories: adsorption, chemical precipitation, membrane separation, and electrocoagulation [6-8]. Among the technologies of fluoride removal coagulation is a simple and effective method in the treatment of drinking water and industrial wastewater. In coagulation $\left(\mathrm{Al}(\mathrm{OH})_{3}\right)$, flocs forms during the hydrolization of Al salt and fluoride is removed by attachment to the flocs [4].

Coagulation is a key and basic unit process in water purification. Coagulation-flocculation followed by clarification is the most widely used process for treating the wastewater. The process usually consists of the rapid dispersal of a coagulant into the wastewater followed by an intense agitation commonly defined as rapid mixing. The most widely used coagulants are aluminum(III) and iron(III) salts [9]. Aluminum (Al) based salts, e.g., polyaluminum chloride (PACl), aluminum chloride $\left(\mathrm{AlCl}_{3}\right)$, and alum (traditional Al coagulants), are most commonly used in water treatment plant. The hydrolysis reactions of Al species are very complicated depending on water quality and coagulant type, which contribute to the formation of various hydrolyzed Al species [10].

Natural waters contain a very wide variety of particulate impurities. These include inorganic substances such as clays and metal oxides, various organic colloids and microbes such as viruses, bacteria, protozoa and algae. Aquatic particles cover a broad range of particle size, from $\mathrm{nm}$ to $\mathrm{mm}$ dimensions and present a significant challenge in water treatment technology [11]. The aim of this work is to remove fluoride from water by coagulation with Alum. Several parameters $(\mathrm{pH}$, coagulant dose, adjuvant dose, flocculent dose and settling time) were studied. In the subsequent step the experimental design methodology using two-level full factorial design was applied to optimize the defluoridation by coagulationflocculation. Then the efficiency of coagulation-flocculation process was evaluated for south Tunisian brackish water containing high fluoride concentration.

\section{EXPERIMENTAL}

\subsection{Reagents}

- Sodium fluoride $\mathrm{NaF}(98,5 \%)$ was purchased from HIMEDIA and used to make fluoride solution.

- Ammonium aluminium sulphate: alum $\mathrm{NH}_{4} \mathrm{Al}\left(\mathrm{SO}_{4}\right)_{2} \cdot 12 \mathrm{H}_{2} \mathrm{O}$, (99\%) from FLUKA was used as a coagulant.

- Magnesium chloride $\left(\mathrm{MgCl}_{2}, 6 \mathrm{H}_{2} \mathrm{O}\right),(99 \%)$ from FLUKA was used as coagulation adjuvant.

- Flocculent : commercial polyelectrolyte (FABI).

\subsection{Analytical methods}

- The fluoride concentrations were measured by means of a fluoride-selective electrode (Radiometer analytical$\mathrm{HACH}$ ). Total fluoride concentration was measured after mixing with total ionic strength adjustment buffer (TISAB) according to the Methods of Examination of Water and Wastewater1.

- $\quad$ The turbidity was measured by turbidmetre (Lovibond Turbidity LAB-IR).

\subsection{Experimental procedures}

In order to conduct coagulation tests a standard jar-test technique was used. Four $1000 \mathrm{~mL}$ volume beakers were filled in with $500 \mathrm{~mL}$ of fluoride solution and placed under the jar-test apparatus, equipped with "lozenge" shaped blades. Then the apparatus was switched on and the mixing rate was set at stirring speed and stirring time. The temperature is around $25^{\circ} \mathrm{C}$. The solution $\mathrm{pH}$ was adjusted at its selected initial value either with dilute $0.1 \mathrm{M} \mathrm{HCl}$ or $0.1 \mathrm{M} \mathrm{NaOH}$ before coagulation, which was measured by $\mathrm{pH}$ meter. Then coagulant dose (alum $\left(\mathrm{NH}_{4} \mathrm{Al}\left(\mathrm{SO}_{4}\right)_{2} .12 \mathrm{H}_{2} \mathrm{O}\right)$ ) was added in solution. The optimal dose of coagulant was combined with magnesium chloride $\left(\mathrm{MgCl}_{2}, 6 \mathrm{H}_{2} \mathrm{O}\right)$ as coagulation adjuvant and commercial flocculent (FABI). The coagulation procedure involved rapid mixing at $250 \mathrm{rpm}$ for $1 \mathrm{~min}$, followed by slow stirring at $50 \mathrm{rpm}$ for $20 \mathrm{~min}$, and a quiescent settling period. Samples were taken from the surface of water and filtered with 0.45 micron filter paper (Millipore) before analysis. The final $\mathrm{pH}$ of the solution for each experiment was measured. The filtrates were analyzed for residual fluoride concentration and residual turbidity. 


\section{RESULTS AND DISCUSSION}

\subsection{Determination of optimal conditions}

Chemical coagulation is a complex phenomenon involving various inter-related parameters, hence it is very critical to define that how well optimal parameters will function under given conditions [12]. First, experiments were conducted in deionized water for examining the behaviour of fluoride in coagulation-flocculation process. The effects of some operating parameters such as: $\mathrm{pH}$, initial fluoride concentration, coagulant dose, adjuvant coagulation dose, flocculent dose and settling time were optimized.

\subsubsection{The effect of initial $\mathrm{pH}$}

Coagulation-flocculation process brings up various mechanisms, often complex and highly dependent on pH [13]. It is therefore necessary to optimize the $\mathrm{pH}$ to determine the $\mathrm{pH}$ range within which coagulation takes place fast enough with a maximum of fluoride removal.

To investigate this effect, a series of experiments were carried out at different initial $\mathrm{pH}\left(\mathrm{pH}_{\mathrm{i}}\right)$ from 4 to 11, coagulant dose was fixed at $5 \mathrm{mg} \mathrm{L}^{-1}$ of aluminium. The variation of $\mathrm{pH}$ after coagulation-flocculation was determined. (Figure 1) depicts the solution $\mathrm{pH}$ after coagulation-flocculation process versus final $\mathrm{pH}$. As seen, for initial $\mathrm{pH}$ varying from 4 to 11 , final $\mathrm{pH}$ drops (3.8-10). This could be attributed to the alkalinity consumption. It can also be noted that the solution $\mathrm{pH}$ variation is practically the same for the studied initial concentrations. For initial $\mathrm{pH}$ varying from $(6$ to 8$)$ the $\mathrm{pH}$ decreases from its initial value to reach a steady state at $\mathrm{pH}$ around 5.5. This result was also reported by Pontié and al. [2] where they deduce that coagulation process causes acidification of the solution.

On the other hand, the evolution of residual fluoride concentration

([F- $\left.]_{\text {res. }}\right)$ for different $\mathrm{pH}_{\mathrm{i}}$ was studied for initial fluoride concentration of 3,6 and $9 \mathrm{mg} \mathrm{L}^{-1}$. As shown in (Figure 2), the effect of the initial $\mathrm{pH}$ solution on fluoride removal is negligible. The maximum difference between residual fluoride concentration at several $\mathrm{pH}_{\mathrm{i}}$ values is almost $0.2 \mathrm{mg} \mathrm{L}^{-1}$.

Similar behaviour has been observed for all studied fluoride concentrations at $\mathrm{pH}_{\mathrm{i}}$ varying from 4 to 11 . Similar results have been found for electrocoagulation process which is an alternative method of chemical coagulation process [14]: The final $\mathrm{pH}$ and residual fluoride concentration did not change very much in the range of initial $\mathrm{pH}$ that is 4-8 because of the buffer capacity of aluminium hydroxide.

It has been reported [9] that at around neutral $\mathrm{pH}, \mathrm{Al}(\mathrm{III})$ has limited solubility, because of the precipitation of an amorphous hydroxide, which can play a very important role in practical coagulation and flocculation processes. More importantly in practice, hydroxide precipitation leads to the possibility of sweep flocculation, in which impurity particles become enmeshed in the growing precipitate and thus effectively removed. Whereas for $\mathrm{Al}$, apart from a narrow $\mathrm{pH}$ region approximately 5-6, the dominant soluble species are $\mathrm{Al}^{3+}$ and $\mathrm{Al}(\mathrm{OH})_{4}^{-}$at low and high $\mathrm{pH}$, respectively. Above approximately $\mathrm{pH}=7$ much larger particles were formed, which settled rapidly to give a reduced turbidity. In the case of aluminium coagulants, optimum $\mathrm{pH}$ values are approximately 7 , close to the minimum solubility. The Al-F complexes were the main species for soluble Al. Furthermore, the transformation of fluoride species and fluoride removal were strongly dependent on $\mathrm{pH}$. Weak acidic conditions were beneficial to the complexation between $\mathrm{Al}$ and fluoride. As $\mathrm{pH}$ increased to 7.0 complexes were completely dissociated to free fluoride. The process of coagulation involved Al-F complexation, Al hydrolysis and precipitation. All the reactions were strongly dependent on $\mathrm{pH}$ and were quick processes with time scale of $10^{2} \mathrm{~s}$. It has been proved that Al-F complexation has an effect on Al hydrolysis. Al-F complexes reacted with less $\mathrm{OH}^{-}$with comparison to $\mathrm{Al}^{3+}$ and were directly precipitated at neutral $\mathrm{pH}$. It was reported that $\mathrm{Al}-\mathrm{F}-\mathrm{OH}$ coprecipitate formed with $\mathrm{Al}-\mathrm{F}$ complexes as precursor in coagulation and the coprecipitation with complexation benefited the removal of fluoride by coagulation [3]. Accordingly, all following coagulation experiments are conducted at initial $\mathrm{pH}=7$.

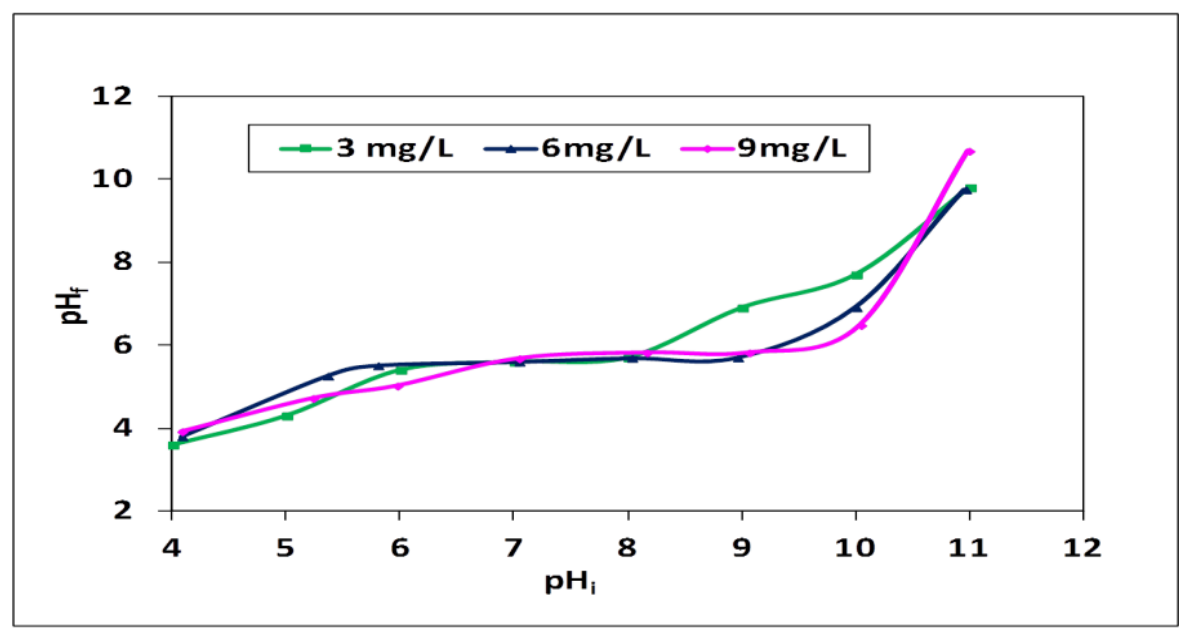

Figure 1: Evolution of final $\mathrm{pH}$ vs initial $\mathrm{pH},\left[\mathrm{Al}^{3+}\right]=5 \mathrm{mg} \mathrm{L}^{-1}$. 


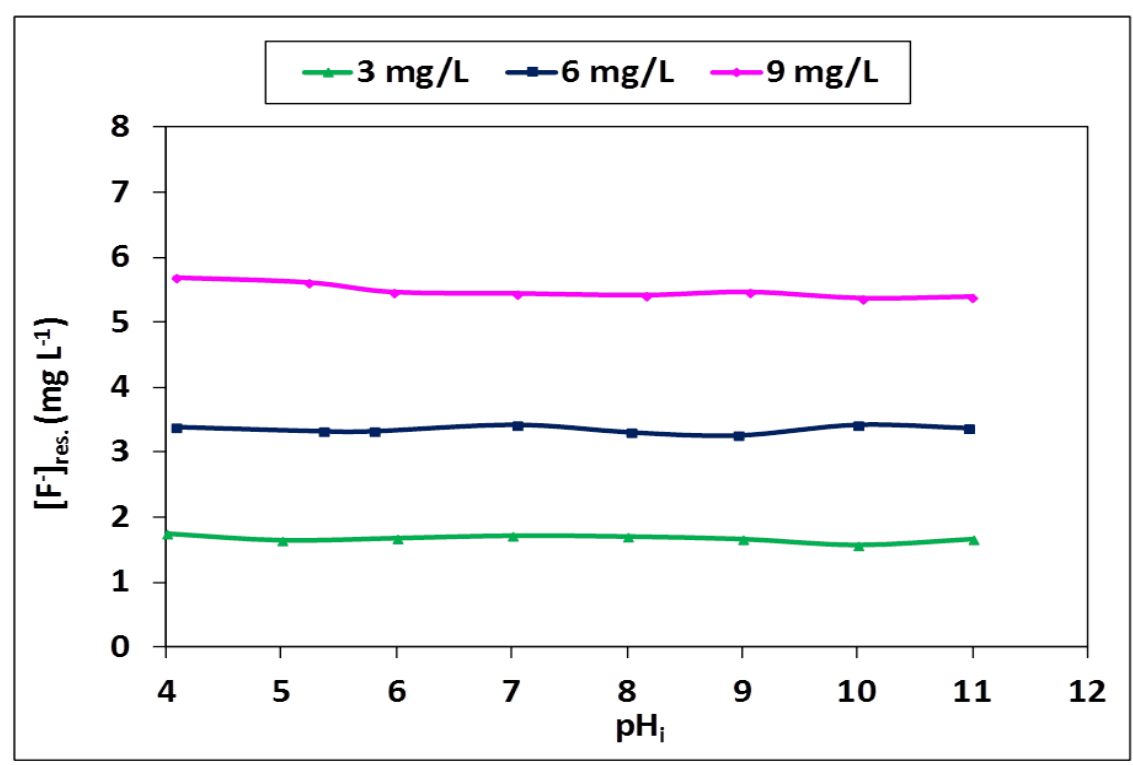

Figure 2: Effect of initial pH solution on residual fluoride concentration for different fluoride concentrations,

$$
\left[\left.A\right|^{3+}\right]=5 \mathrm{mg} \mathrm{L}^{-1} \text {. }
$$

\subsubsection{The effect of initial fluoride concentration}

To determine the effect of the initial concentration of fluoride, different jar tests were carried out with increasing amounts of coagulants starting from $2 \mathrm{mg} \mathrm{L}^{-1}$ up to $35 \mathrm{mg} \mathrm{L}^{-1}$. Initials fluoride concentrations studied are 3,6 and $9 \mathrm{mg} \mathrm{L}^{-1}$. Considering (Figure 3 ), it was observed that the removal efficiency of fluoride was closely related with its initial concentration. Fluoride removal decreases from $61 \%$ to $58 \%$ for a coagulant dose of $5 \mathrm{mg} \mathrm{L}^{-1}$ and initial fluoride concentration of 3 and $9 \mathrm{mg} \mathrm{L}^{-1}$ respectively.
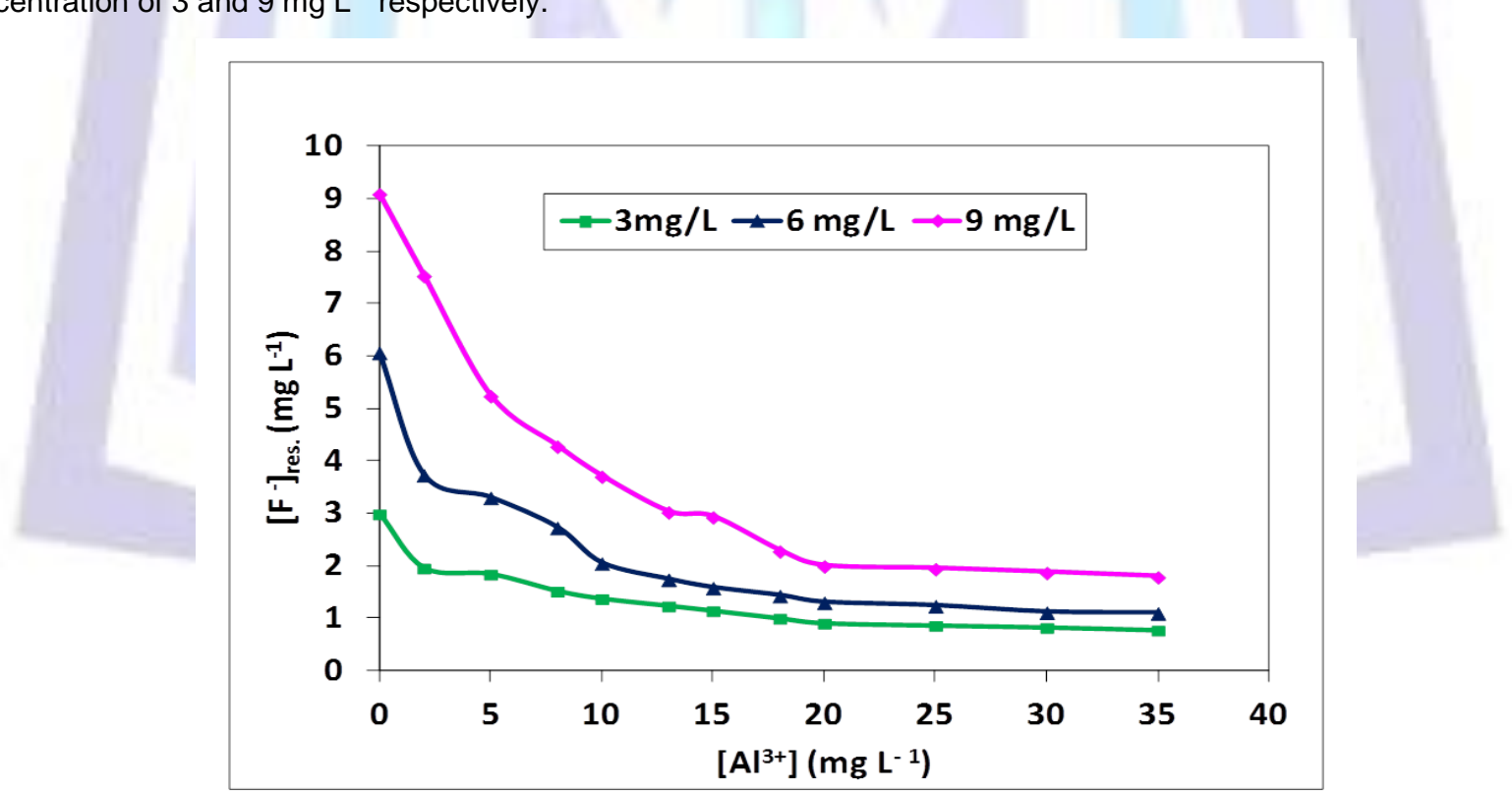

Figure 3: Effect of coagulant dose on residual fluoride concentration for different initial fluoride concentrations, $\mathrm{pH}_{\mathrm{i}}=7$.

The appearance of the curves (Figure 3) shows a similar behavior: rapid reduction followed by a constant level. Residual fluoride concentration tends to decrease by increasing aluminum amount up to $20 \mathrm{mg} \mathrm{L}^{-1}$. However, with further coagulant increase, removal did not improve. Aluminum dose of $20 \mathrm{mg} \mathrm{L}^{-1}$ results in a decrease of fluoride concentrations from 3,6 and $9 \mathrm{mg} \mathrm{L}^{-1}$ to $0.9,1.42$ and $1.99 \mathrm{mg} \mathrm{L}^{-1}$ corresponding to a fluoride removal of about 30,24 and $22 \%$ respectively. Previous study has revealed that coagulation process is effective in waters with low or medium levels of fluoride [15]. Indeed, at neutral conditions higher fluoride concentration induced more Al-F complexes. High fluoride concentration is advantageous for Al-F complexation which increased the content of soluble Al but disadvantageous for fluoride removal [3]. This is confirmed by our coagulation experiments. In fact, with a coagulant dose of $35 \mathrm{mg} \mathrm{L}^{-1}$, residual fluoride concentrations reached 0.77 and $1.11 \mathrm{mg} \mathrm{L}^{-1}$ for initials concentrations of fluoride 3 and $6 \mathrm{mg} \mathrm{L}^{-1}$ respectively. 
However, this dose is insufficient for an initial fluoride concentration $9 \mathrm{mg} \mathrm{L}^{-1}$. Indeed the residual fluoride concentration is about $1.8 \mathrm{mg} \mathrm{L}^{-1}$.

\subsubsection{The effect of coagulant dose}

The effect of coagulant dose on removal efficiency of fluoride was investigated for different fluoride initial concentration of 3, 6 and $9 \mathrm{mg} \mathrm{L}^{-1}$ of fluoride. To optimize the coagulant dose, different jar tests were performed with increasing amounts of aluminum up to $35 \mathrm{mg} \mathrm{L}^{-1}$. The obtained results are shown in (Figure 4). The alum coagulation and flocculation efficiency was improved with the increasing of coagulant dose. Similar behavior has been observed for different initials fluoride concentrations studied.

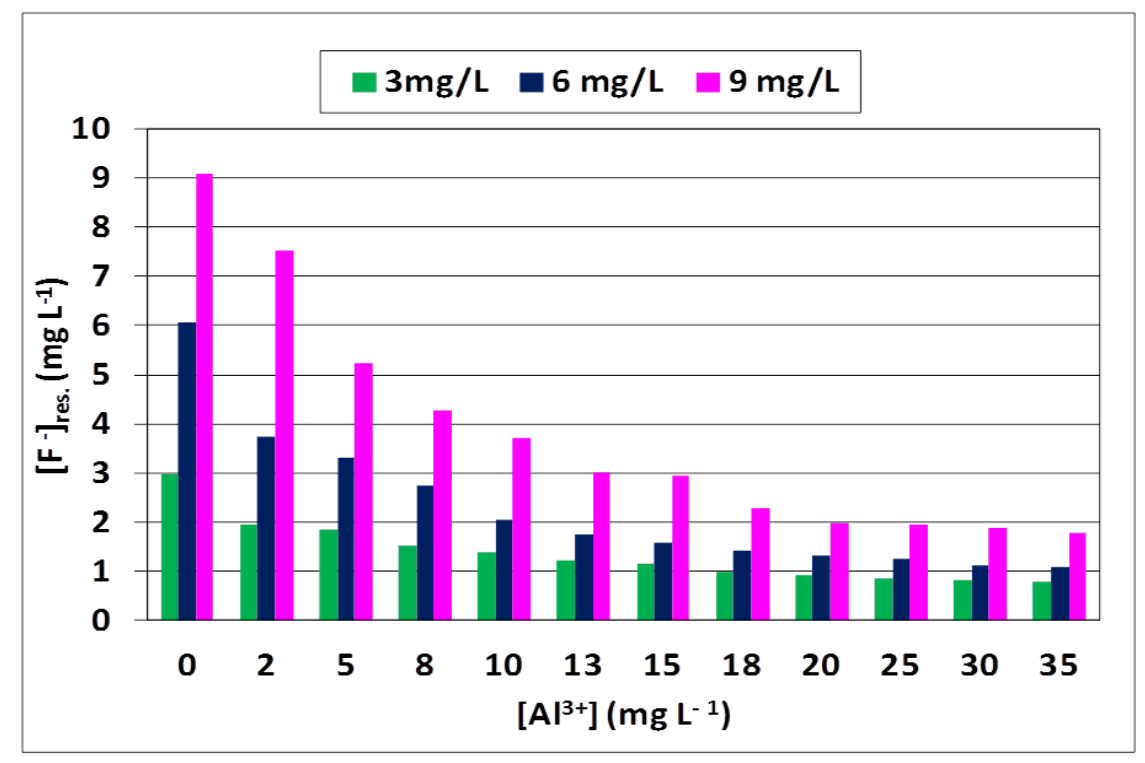

Figure 4: Evolution of residual fluoride vs aluminum dose for different concentrations, $\mathrm{pH}_{\mathrm{i}}=7$.

The obtained results allow us to choose optimal coagulant dose $\left(\left[\mathrm{Al}^{3+}\right]_{\text {opt. }}\right)$ for the different studied fluoride concentrations. As shown in (Table 1), according to experimental results, all following coagulation experiments are conducted at optimal coagulation doses, to improve the fluoride removal efficiency and to minimize excessive doses of aluminum.

Table 1. Residual fluoride concentrations and optimal coagulant doses for different fluoride initial concentrations, $\mathrm{pH}_{\mathrm{i}}=7$.

\begin{tabular}{|c|c|c|}
\hline$\left[F_{0}\right]_{0}\left(\mathrm{mg} \mathrm{L}^{-1}\right)$ & {$\left[\mathrm{Al}^{3+}\right]_{\text {opt. }}\left(\mathrm{mg} \mathrm{L}^{-1}\right)$} & {$[\mathbf{F}]_{\text {res. }}\left(\mathrm{mg} \mathrm{L}^{-1}\right)$} \\
\hline 3 & 8 & 1.52 \\
\hline 6 & 13 & 1.75 \\
\hline 9 & 20 & 2.00 \\
\hline
\end{tabular}

\subsubsection{The effect of coagulation adjuvant dose}

In order to examine the effect of magnesium chloride $\left(\mathrm{MgCl}_{2}, 6 \mathrm{H}_{2} \mathrm{O}\right)$ as coagulation adjuvant on fluoride removal, different coagulation tests were carried out by combining the optimal dose of coagulant with increasing adjuvant dose starting with $200 \mathrm{mg} \mathrm{L}^{-1}$ and increasing this by $200 \mathrm{mg} \mathrm{L}^{-1}$ increments up to $1200 \mathrm{mg} \mathrm{L}^{-1}$.

(Figure 5), presents the results obtained by varying the adjuvant dose for different initials fluoride concentrations. It was observed that residual fluoride concentration decreased with increasing the dose of the coagulation adjuvant. An analogous behavior has been found for all fluoride concentrations studied. The increasing of defluoridation rate when the dose of the coagulation adjuvant $\left(\mathrm{MgCl}_{2}, 6 \mathrm{H}_{2} \mathrm{O}\right)$ increases is probably attributed to the dominant phenomenon of the adsorption of $\mathrm{F}^{-}$on the sites of magnesia $\mathrm{Mg}(\mathrm{OH})_{2}$ formed by the presence of sufficient amount of magnesium ions in water. This, because the particles of $\mathrm{Mg}(\mathrm{OH})_{2}$ have a positive electrical charge in the total pH range of their existence [15]. 


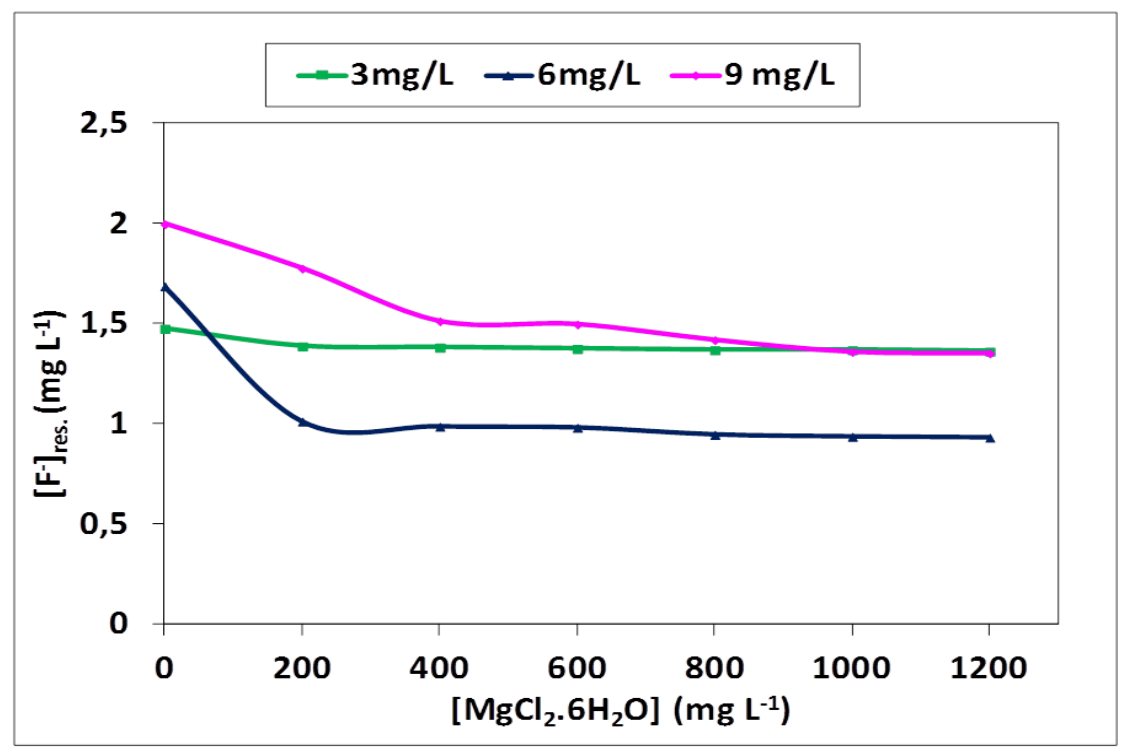

Figure 5: Variation of the residual fluoride concentration for different coagulation adjuvant doses, $\mathrm{pH}_{\mathrm{i}}=7$.

The obtained results allows us to choose optimal adjuvant dose $\left(\left[\mathrm{MgCl}_{2} \cdot 6 \mathrm{H}_{2} \mathrm{O}\right]_{\text {opt. }}\right)$ for the studied fluoride concentrations as shown in (Table 2).

Table 2. Residual fluoride concentrations and optimal adjuvant doses for different initial fluoride concentrations.

\begin{tabular}{|c|c|c|c|}
\hline $\begin{array}{c}{\left[\mathrm{F}^{-}\right]_{0}} \\
\left(\mathrm{mg} \mathrm{L}^{-1}\right)\end{array}$ & $\begin{array}{c}{\left[\mathrm{Al}^{3+}\right]_{\text {opt. }}} \\
\left(\mathrm{mg} \mathrm{L}^{-1}\right)\end{array}$ & $\begin{array}{c}{\left[\mathrm{MgCl}_{2} \cdot 6 \mathrm{H}_{\mathbf{2}} \mathrm{O}\right]_{\text {opt. }}} \\
\left(\mathrm{mg} \mathrm{L}^{-1}\right)\end{array}$ & $\begin{array}{c}{[\mathrm{F}]_{\text {res. }}} \\
\left(\mathrm{mg} \mathrm{L}^{-1}\right)\end{array}$ \\
\hline 3 & 8 & 200 & 1.39 \\
\hline 6 & 13 & 200 & 1.01 \\
\hline 9 & 20 & 800 & 1.42 \\
\hline
\end{tabular}

\subsubsection{The effect of flocculent dose}

The main objective of flocculation step is the agglomeration of the particles until have up to a size of an agglomerate can decant, with the addition of a flocculent [16]. It is therefore necessary to optimize the dose of flocculent. Coagulation tests were performed to investigate the influence of the flocculent on fluoride removal by combining the optimal coagulant dose with different doses of commercial flocculent (FABI) varying from 0.6 to $4.2 \mathrm{mg} \mathrm{L}^{-1}$. It should be noted that the study was conducted in the absence and presence of optimal adjuvant dose to determine the effect of flocculent alone and in combination with adjuvant and coagulant doses. Fluoride concentrations studied are 3,6 and $9 \mathrm{mg} \mathrm{L}^{-1}$. The results showing the variation of the residual fluoride concentration and the turbidity are given in (Figure 6) and (Figure 7).

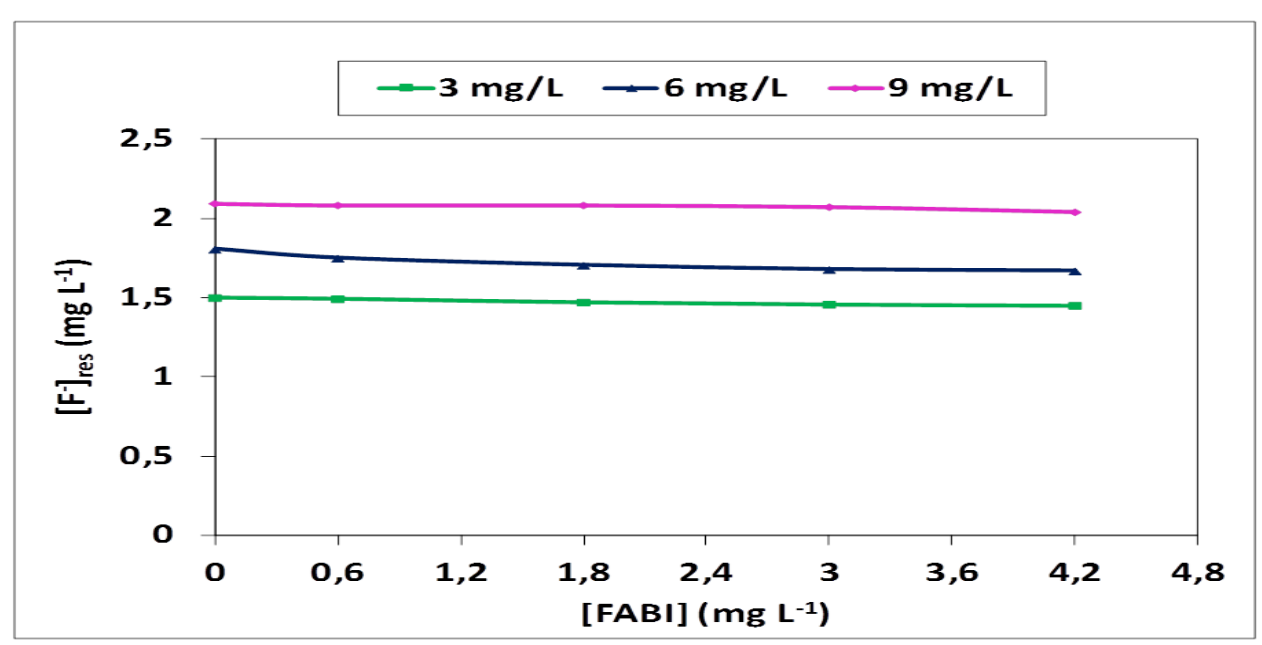

Figure 6a: Variation of the residual fluoride concentration for different flocculent doses (without adjuvant), $\mathrm{pH}_{\mathrm{i}}=7$. 


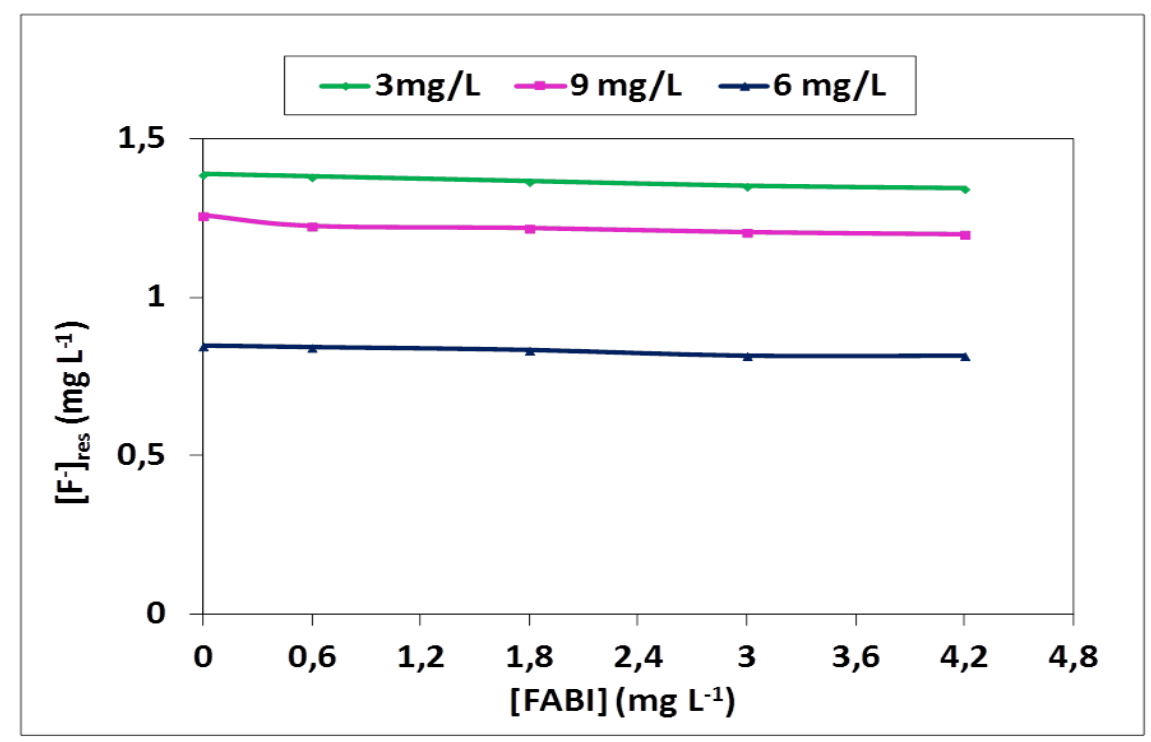

Figure 6b: Variation of the residual fluoride concentration for different flocculent doses, (with adjuvant: $\left[\mathrm{MgCl}_{2} \cdot 6 \mathrm{H}_{2} \mathrm{O}\right]_{\text {opt. }}$ : Table 2.), $\mathrm{pH}_{\mathrm{i}}=7$.

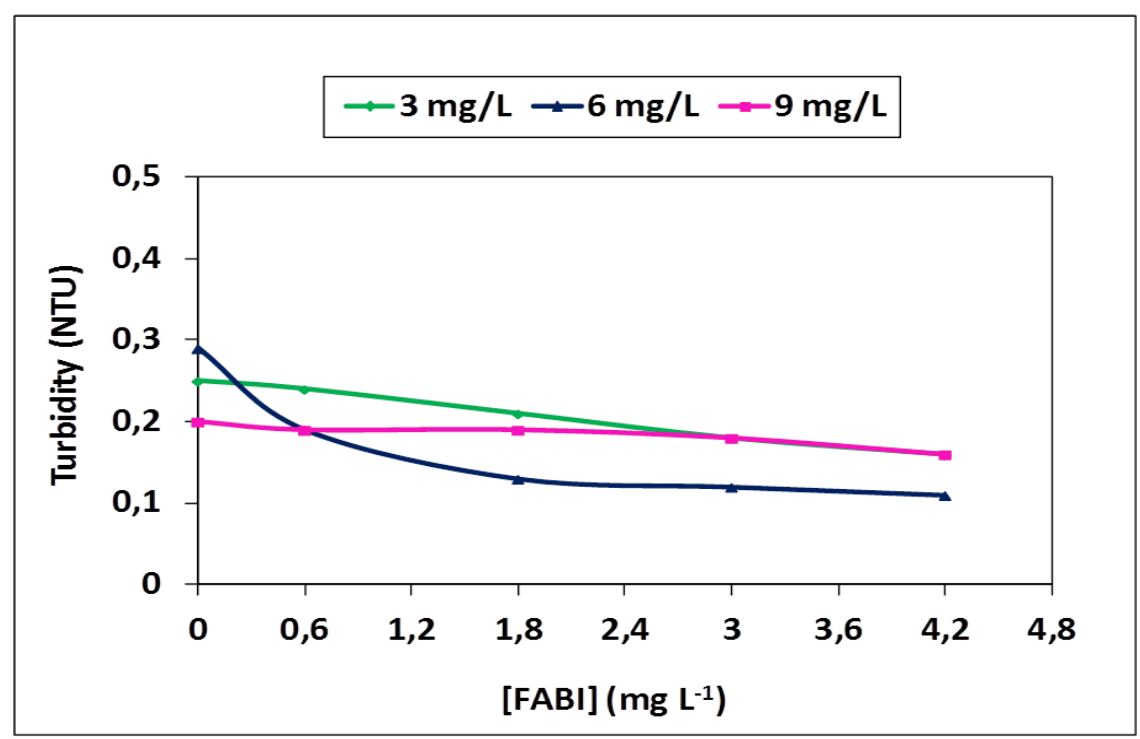

Figure 7a: Variation of solution turbidity for different flocculent dose, (without adjuvant), $\mathrm{pH}_{\mathrm{i}}=7$. 


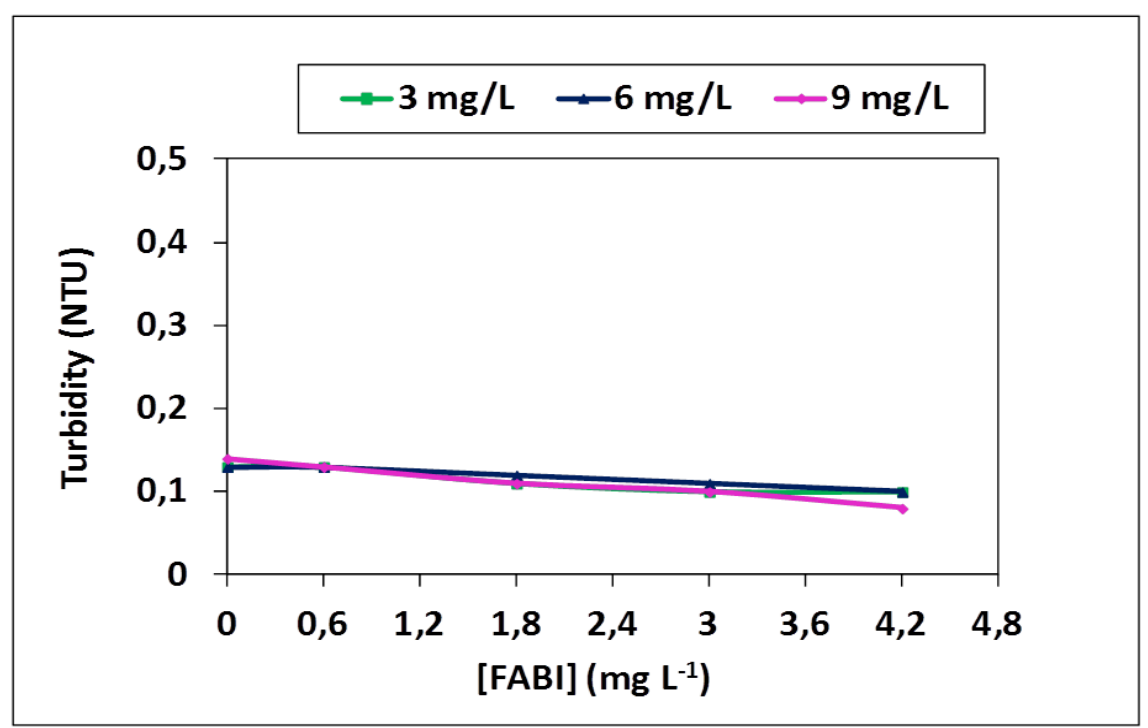

Figure 7b: Variation of solution turbidity for different flocculent dose,

(with adjuvant), $\mathrm{pH}_{\mathrm{i}}=7$.

As shown in (Figure 6a) and (Figure 6b), the effect of flocculent dose on residual fluoride concentration is negligible for all studied fluoride concentrations. However, increasing flocculent dose results in a significant decrease of the solution turbidity (Figure 7a and Figure 7b). Increasing flocculent dose leads to a more rapid flocculation and strong flocs. Analogous behavior was found for the two cases: with and without optimal adjuvant dose. According to experimental results $\mathrm{FABI}$ amount of $4.2 \mathrm{mg} \mathrm{L}^{-1}$ was chosen as an optimal flocculent dose. Experimental obtained results are shown in (Table 3).

Table 3. Effect of adjuvant on residual fluoride concentration and solution turbidity,

$$
\left.\mathrm{pH}_{\mathrm{i}}=7 \text {, [FABI }\right]_{\text {opt. }}=4.2 \mathrm{mg} \mathrm{L}^{-1} \text {. }
$$

\begin{tabular}{|c|c|c|c|}
\hline$[F]_{0}\left(\mathrm{mg} \mathrm{L}^{-1}\right)$ & Parameter & $\begin{array}{l}\text { Without } \\
\text { adjuvant }\end{array}$ & $\begin{array}{c}\text { With } \\
\text { adjuvant }\end{array}$ \\
\hline 3 & {$\left[F^{-}\right]_{\text {res. }}\left(\mathrm{mg} \mathrm{L}^{-1}\right)$} & 1.45 & 1.34 \\
\hline & Turbidité (NTU) & 0.16 & 0.10 \\
\hline & {$[F]_{\text {res. }}\left(\mathrm{mg} \mathrm{L}^{-1}\right)$} & 1.67 & 0.81 \\
\hline & Turbidité (NTU) & 0.11 & 0.10 \\
\hline \multirow{2}{*}{9} & {$\left[\mathrm{~F}^{-}\right]_{\text {res. }}\left(\mathrm{mg} \mathrm{L}^{-1}\right)$} & 2.04 & 1.20 \\
\hline & Turbidité (NTU) & 0.16 & 0.08 \\
\hline
\end{tabular}

Some researchers [17] have studied the relationships between residual turbidity and aluminum in treated water: when turbidity in treated water after filtration was controlled to $0.1 \mathrm{NTU}$, the concentrations of residual aluminum could be reduced to $0.02 \mathrm{mg} \mathrm{L}^{-1}$. As a result, controlling residual turbidity of treated water was very important, and it was directly connected with the concentrations of residual aluminum in treated water.

\subsubsection{The effect of settling time}

Various coagulation tests were performed to investigate the effect of settling time by combining the optimal coagulant dose with optimal adjuvant and optimal flocculent dose (fixed at $4.2 \mathrm{mg} \mathrm{L}^{-1}$ ) for different settling time. Fluoride concentrations studied are 3,6 and $9 \mathrm{mg} \mathrm{L}^{-1}$. The results showing the variation of the residual fluoride concentration and the turbidity are shown in (Figure $8 \mathrm{a}$ and Figure $8 \mathrm{~b}$ ). The increase of the settling time results in a decrease of residual fluoride concentration which could be attributed to an adsorption process by $\mathrm{Al}(\mathrm{OH})_{3}$ flocs. During the adsorption process, 
fluoride was removed by ion exchange with $\mathrm{OH}^{-}$. The acidic condition $\left(\mathrm{pH}_{\mathrm{f}}=5.5\right)$ favored the release of $\mathrm{OH}^{-}$and fluoride removal. This slow reaction of ion exchange required more time to achieve equilibrium [3].

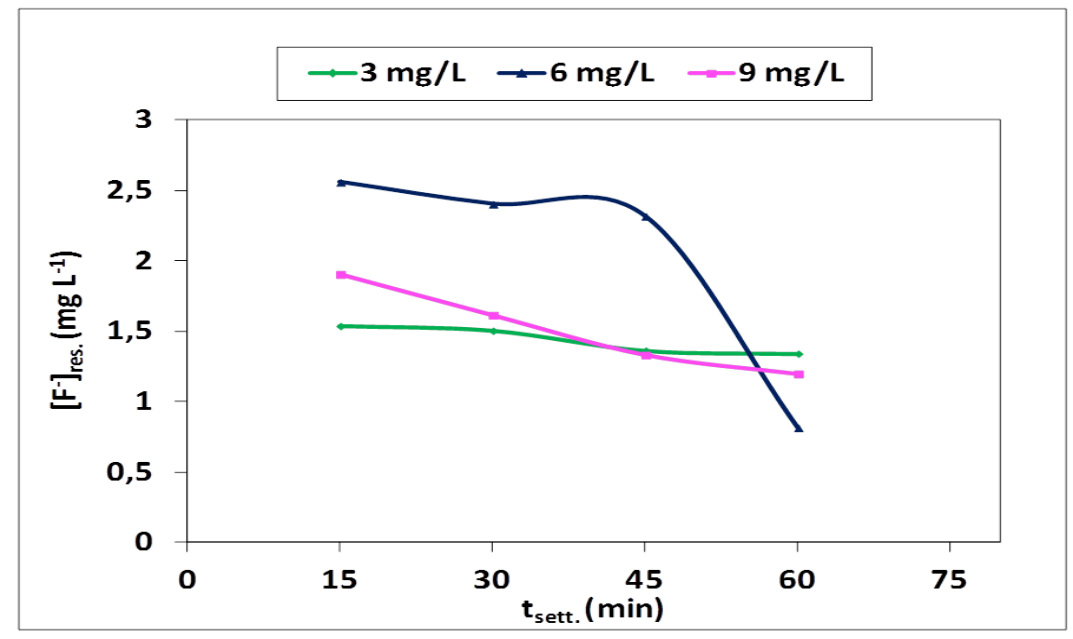

Figure 8a. Evolution of residual fluoride concentration vs settling time,

$$
\mathrm{pH}_{\mathrm{i}}=7 \text {, }[\mathrm{FABI}]_{\text {opt. }}=4.2 \mathrm{mg} \mathrm{L}^{-1} \text {. }
$$

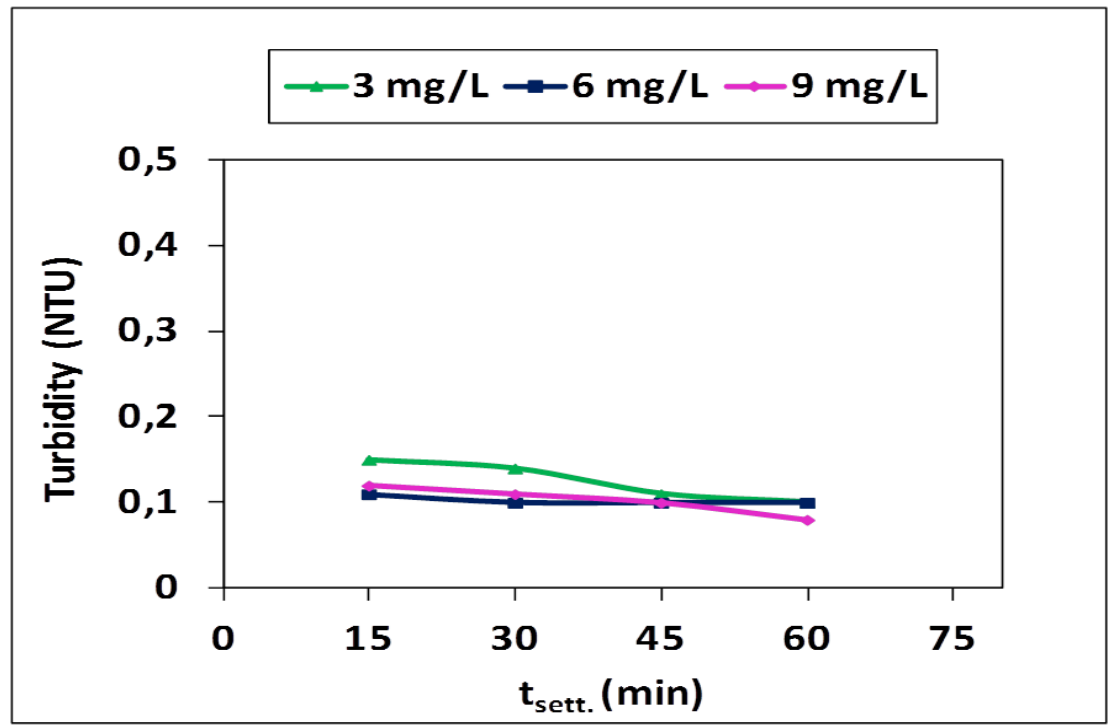

Figure 8b: Evolution of solution turbidity vs settling time, $\mathrm{pH}_{\mathrm{i}}=7$, $[\mathrm{FABI}]_{\mathrm{opt}}=4.2 \mathrm{mg} \mathrm{L}^{-1}$.

Optimal settling time is the time for which residual fluoride concentration and residual turbidity are minimal. According to our experimental results optimal settling time is $60 \mathrm{~min}$.

\subsection{Experimental design methodology}

We have investigated the influence of four main parameters: initial fluoride concentration $\left(\left[\mathrm{F}_{0}\right]_{0}\right)$, coagulant dose $\left(\left[\mathrm{Al}^{3+}\right]\right)$, coagulation adjuvant dose $\left(\left[\mathrm{MgCl}_{2} \cdot 6 \mathrm{H}_{2} \mathrm{O}\right]\right)$ and settling time $\left(\mathrm{t}_{\text {sett. }}\right)$ on the defluoridation by coagulation-flocculation using the experimental design methodology by means of factorial matrix $\left(2^{k}\right)[18]$.

In these types of designs, variables $(k)$ are set at two levels: low and high normalized as $(-1)$ and $(+1)$. With these designs, it was possible to calculate the average and the principle effects of each factors and their interaction.

The experimental response associated to a $2^{k}$ factorial design (for 4 variables) is represented by a linear polynomial model equation :

$$
Y=b_{0}+b_{1} X_{1}+b_{2} X_{2}+b_{3} X_{3}+b_{4} X_{4}+b_{12} X_{1} X_{2}+b_{13} X_{1} X_{3}+b_{14} X_{1} X_{4}+b_{23} X_{2} X_{3}+b_{24} X_{2} X_{4}+b_{34} X_{3} X_{4}
$$

Where:

- Y : experimental response, 
- $\mathrm{X}_{\mathrm{i}}$ : coded variable $(-1$ or +1$)$,

- $b_{i}$ : estimation of the principal effect of the factor $i$ for the response $Y$,

- $b_{i j}$ : estimation of interaction effect between factor $\mathrm{i}$ and $\mathrm{j}$ for the response $\mathrm{Y}$.

The response investigated is the residual fluoride concentration ([F] $\left.]_{\text {res. }}\right)$. The coefficients of the equation model were calculated in the experimental field listed in (Table 4).

Table 4: Experimental region investigated for fluoride removal by coagulation-flocculation.

\begin{tabular}{clcc}
\hline $\begin{array}{c}\text { Coded } \\
\text { variables }\left(\mathrm{X}_{\mathrm{i}}\right)\end{array}$ & \multicolumn{1}{c}{ Factors } & \multicolumn{2}{c}{ Experimental field } \\
\cline { 3 - 4 } & & $\begin{array}{c}\text { Minimum } \\
\text { level value }\end{array}$ & $\begin{array}{c}\text { Maximum } \\
\text { level value }\end{array}$ \\
\hline $\mathrm{X}_{1}$ & initial fluoride concentration: $\left[\mathrm{F}^{-}\right]_{0}\left(\mathrm{mg} \mathrm{L}^{-1}\right)$ & 3 & 9 \\
$\mathrm{X}_{2}$ & coagulant dose: $\left[\mathrm{Al}^{3+}\right]\left(\mathrm{mg} \mathrm{L}^{-1}\right)$ & 2 & 20 \\
$\mathrm{X}_{3}$ & coagulation adjuvant dose: $\left[\mathrm{MgCl}_{2} \cdot 6 \mathrm{H}_{2} \mathrm{O}\right]\left(\mathrm{mg} \mathrm{L}^{-1}\right)$ & 0 & 800 \\
$\mathrm{X}_{4}$ & settling time: $t_{\text {set. }}(\min )$ & 15 & 60 \\
\hline
\end{tabular}

The experimental design and results are represented in (Table 5).

Table 5. Factorial experimental design, experimental plan and results.

\begin{tabular}{|c|c|c|c|c|c|c|c|c|c|}
\hline \multirow{2}{*}{$\begin{array}{c}\text { Experiment } \\
\text { number }\end{array}$} & \multicolumn{4}{|c|}{ Experimental design } & \multicolumn{4}{|c|}{ Experimental plan } & \multirow{2}{*}{$\begin{array}{c}\mathbf{Y} \\
{[\mathrm{F}]_{\text {res. }}} \\
\left(\mathrm{mg} \mathrm{L}^{-1}\right)\end{array}$} \\
\hline & $X_{1}$ & $X_{2}$ & $X_{3}$ & $X_{4}$ & $\begin{array}{c}\left.\mathrm{F}^{-}\right]_{0} \\
\left(\mathrm{mg} \mathrm{L}^{-1}\right)\end{array}$ & $\begin{array}{c}{\left[\mathrm{Al}^{3+}\right]} \\
\left(\mathrm{mg} \mathrm{L}^{-1}\right)\end{array}$ & $\begin{array}{c}{\left[\mathrm{MgCl}_{2} \cdot 6 \mathrm{H}_{2} \mathrm{O}\right]} \\
\left(\mathrm{mg} \mathrm{L}^{-1}\right)\end{array}$ & $\begin{array}{l}t_{\text {sett. }} \\
(\min )\end{array}$ & \\
\hline 1 & -1 & -1 & -1 & -1 & 3 & 2 & 0 & 15 & 2.07 \\
\hline 2 & +1 & -1 & -1 & -1 & 9 & 2 & 0 & 15 & 8.47 \\
\hline 3 & -1 & +1 & -1 & -1 & 3 & 20 & 0 & 15 & 1.64 \\
\hline 4 & +1 & +1 & -1 & -1 & 9 & 20 & 0 & 15 & 4.27 \\
\hline 5 & -1 & -1 & +1 & -1 & 3 & 2 & 800 & 15 & 2.00 \\
\hline 6 & 1 & -1 & +1 & -1 & 9 & 2 & 800 & 15 & 7.60 \\
\hline 7 & -1 & +1 & +1 & -1 & 3 & 20 & 800 & 15 & 1.31 \\
\hline 8 & +1 & +1 & +1 & -1 & 9 & 20 & 800 & 15 & 3.42 \\
\hline 9 & -1 & -1 & -1 & +1 & 3 & 2 & 0 & 60 & 2.00 \\
\hline 10 & +1 & -1 & -1 & +1 & 9 & 2 & 0 & 60 & 7.43 \\
\hline 11 & -1 & +1 & -1 & +1 & 3 & 20 & 0 & 60 & 0.90 \\
\hline 12 & +1 & +1 & -1 & +1 & 9 & 20 & 0 & 60 & 1.99 \\
\hline 13 & -1 & -1 & 1 & +1 & 3 & 2 & 800 & 60 & 1.85 \\
\hline 14 & +1 & -1 & 1 & +1 & 9 & 2 & 800 & 60 & 4.56 \\
\hline 15 & -1 & +1 & 1 & +1 & 3 & 20 & 800 & 60 & 1.29 \\
\hline 16 & +1 & +1 & 1 & +1 & 9 & 20 & 800 & 60 & 1.25 \\
\hline
\end{tabular}

According to the results obtained the coefficients of the polynomial model were calculated using the Nemrod-W Software:

$Y=3.25+1.62 X_{1}-1.24 X_{2}-0.34 X_{3}-0.59 X_{4}-0.9 X_{1} X_{2}-0.32 X_{1} X_{3}-0.47 X_{1} X_{4}+0.15 X_{2} X_{3}-0.06 X_{2} X_{4}-0.08 X_{3} X_{4}$ 
The effects and interactions of the various investigated factors are represented in (Figure 9).

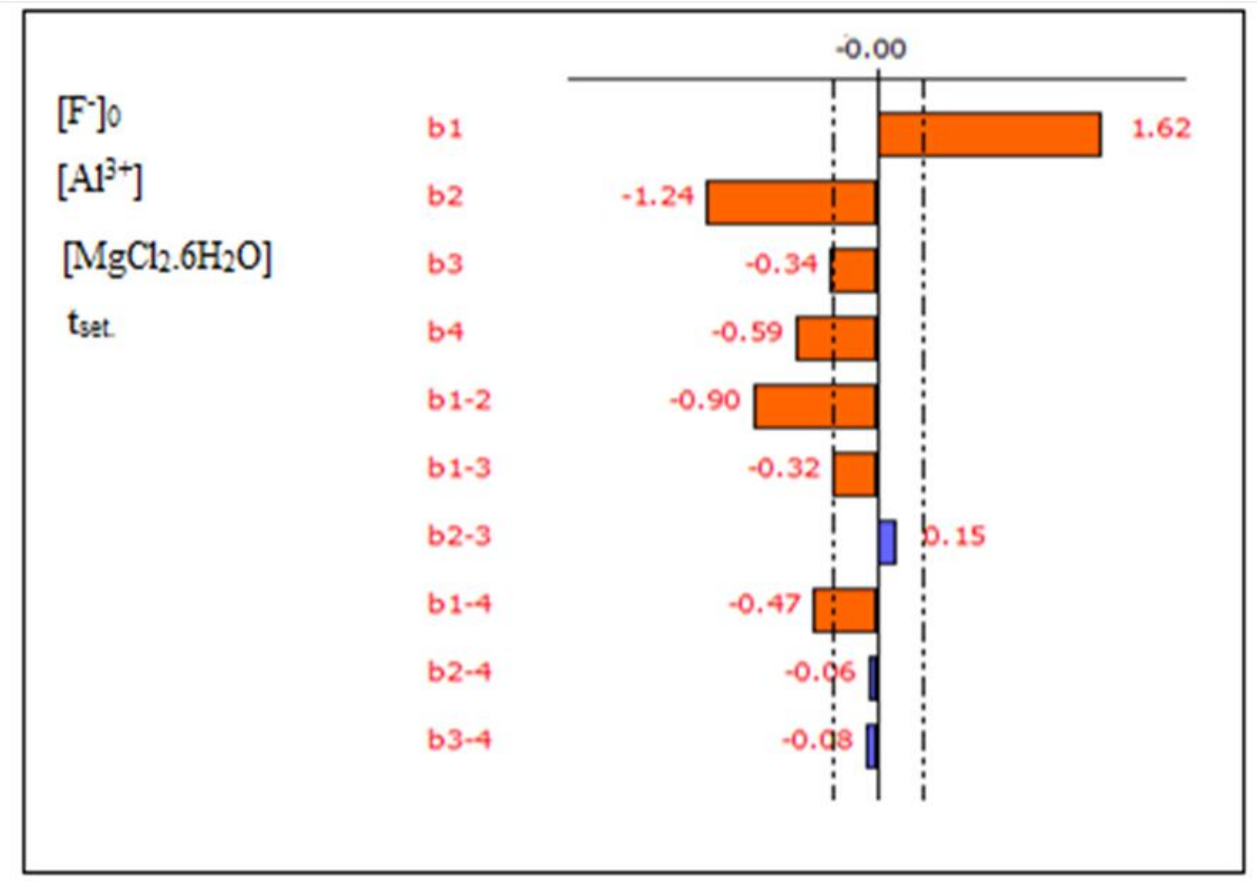

Figure 9: Graphical analysis of the effect of : $\left[\mathrm{F}^{-}\right]_{0},\left[\mathrm{Al}^{3+}\right],\left[\mathrm{MgCl}_{2} \cdot 6 \mathrm{H}_{2} \mathrm{O}\right]$ and the $\mathrm{t}_{\text {sett. }}$ on fluoride removal by coagulation-flocculation.

It was concluded that initial fluoride concentration $\left[\mathrm{F}^{-}\right]_{0}$ has the highest effect. The effect of $\left[\mathrm{F}^{-}\right]_{0}$ is positive, so it seems that residual fluoride concentration increases when initial fluoride concentration increases. In addition, the coagulant dose $\left[\mathrm{Al}^{3+}\right]$ is the second most significant factor on fluoride removal. Its effect is negative. The increase of coagulant dose leads to decrease the residual fluoride concentration.

The coefficient associated with the interaction term $\left(X_{1} X_{2}\right)$ has an important value (0.9). Therefore, the effect of variable $\mathrm{X}_{2}\left(\left[\mathrm{Al}^{3+}\right]\right)$ depend on the level of variable $\mathrm{X}_{1}\left([\mathrm{~F}]_{0}\right)$ and vice versa, in the experimental region investigated. This interaction has a negative effect on the studied response ([F] $\left.]_{\text {res. }}\right)$. From the statistical analysis, it is inferred that settling time ( $\left.t_{\text {sett. }}\right)$ and coagulation adjuvant dose $\left(\left[\mathrm{MgCl}_{2} \cdot 6 \mathrm{H}_{2} \mathrm{O}\right]\right)$ have a considerable effects on fluoride removal by coagulationflocculation, but slightly lower than $[\mathrm{F}]_{0}$ and $\left[\mathrm{Al}^{3+}\right]$ effects. Also the interactions terms $\left(\mathrm{X}_{1} \mathrm{X}_{3}\right)$ and $\left(\mathrm{X}_{1} \mathrm{X}_{4}\right)$ are significant and have negatives degree respectively $(0.32)$ and $(0.47)$. Therefore, the effect of variable $X_{1}\left([F]_{0}\right)$ depend on the level of variable $\mathrm{X}_{3}$ (coagulation adjuvant dose $\left(\left[\mathrm{MgCl}_{2} \cdot 6 \mathrm{H}_{2} \mathrm{O}\right]\right)$. Then the effect of variable $\mathrm{X}_{1}\left([\mathrm{~F}]_{0}\right)$ depend on the level of variable $\mathrm{X}_{4}$ (settling time $\left.\left(\mathrm{t}_{\text {sett. }}\right)\right)$ and vice versa, in the experimental region investigated. Nevertheless the interaction term $\left(\mathrm{X}_{2} \mathrm{X}_{4}\right)$ and $\left(X_{3} X_{4}\right)$ have negatives effects but are not significant, in fact the coefficients associated has an low values respectively $(0.06)$ and (0.08). Dissimilar effect was seen with the interaction term $\left(X_{2} X_{3}\right)$, with positive small degree $(0.15)$, but is not so significant Pareto analysis [19] gives more significant information to interpret these results. In fact, this analysis calculates the percentage effect of each factor on the response according to the following relation:

$$
P_{i}=\frac{b_{i}^{2}}{\sum b_{i}^{2}} \times 100 \quad(i \neq 0)
$$

Where $b_{i}$ represents the estimation of the principal effect of the factor $i$ for the response.

(Figure 10) represents the Pareto graphic analysis. 


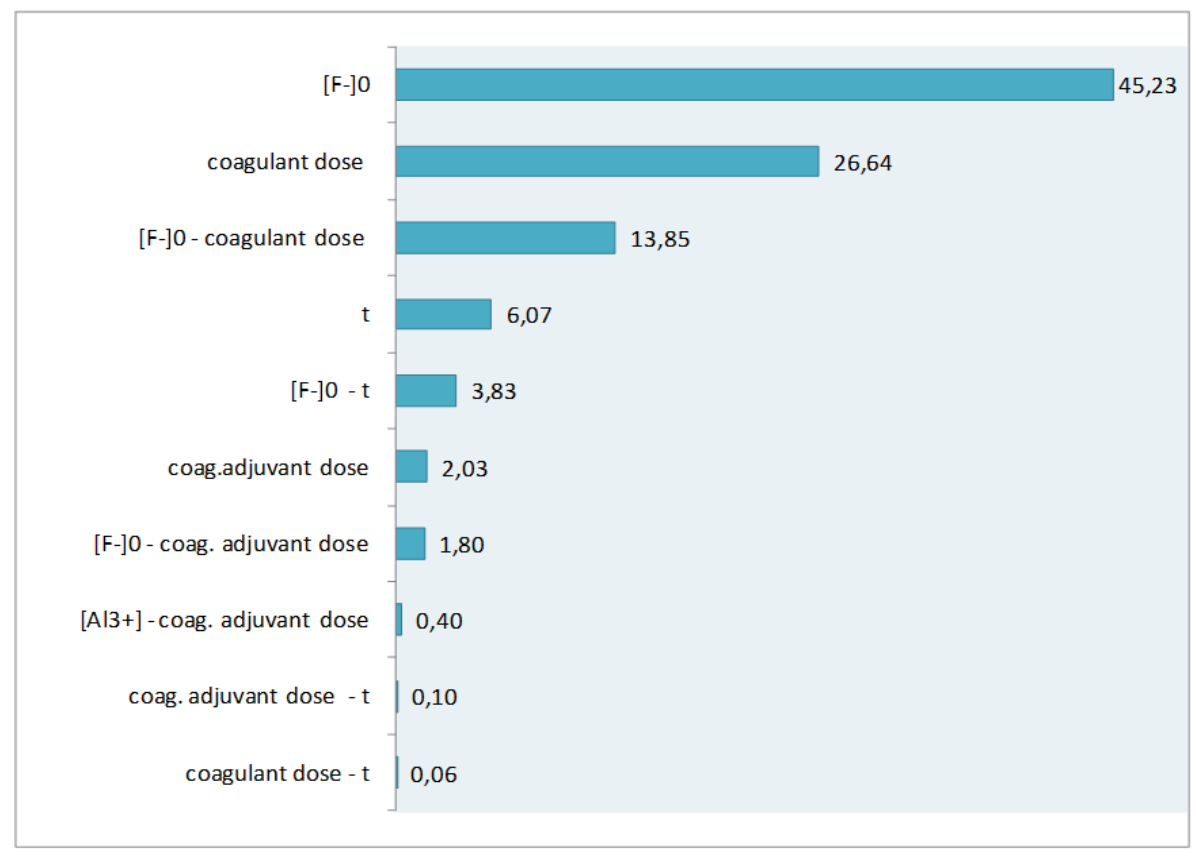

Figure 10: Graphical Pareto analysis.

Figure 10 , shows that initial fluoride concentration $\left[\mathrm{F}^{-}\right]_{0}$, coagulant dose $\left[\mathrm{Al}^{3+}\right]$ and their interaction are the most determining factors on the removal of fluoride by coagulation-flocculation. In fact, $85.72 \%$ of the response are bringing by these two factors and their interaction. Additionally, with settling time, interaction ([F] $]_{0}$ settling time.) and coagulation adjuvant dose, the investigated response achieve $97.65 \%$. However, the other interactions of the various investigated factors have a negligible effect; they represent a small degree about $2 \%$ of the response. As a consequence, in the experimental region investigated initial fluoride concentration, coagulant dose, their interaction and settling time have a considerable effect for the best removal of fluoride by coagulation-flocculation.

\subsection{Application}

In order to study the applicability of the process, experiments were conducted to determine the effectiveness of coagulation-flocculation treatment for fluoride removal from natural waters of south Tunisian. Before starting the coagulation tests, were determined the main quality parameters of the water sample (Water Oued El Maleh-Gafsa). The results are summarized in Table 6.

Table 6. Physico-chemical characteristics of the sample.

\begin{tabular}{|c|c|}
\hline Parameter & Sample \\
\hline Conductivity $\left(\mu \mathrm{S} \mathrm{cm}^{-1}\right)$ & 7970.00 \\
\hline Salinity $\left(\mathrm{mg} \mathrm{L}^{-1}\right)$ & 6045.60 \\
\hline $\mathrm{pH}$ & 7.40 \\
\hline Turbidity $(\mathrm{NTU})$ & 1.34 \\
\hline$\left[\mathrm{Ca}^{2+}\right]\left(\mathrm{mg} \mathrm{L}^{-1}\right)$ & 240.00 \\
\hline$\left[\mathrm{Mg}^{2+}\right]\left(\mathrm{mg} \mathrm{L}^{-1}\right)$ & 97.20 \\
\hline$\left[\mathrm{F}^{-}\right]\left(\mathrm{mg} \mathrm{L}^{-1}\right)$ & 3.42 \\
\hline
\end{tabular}

Physico-chemical characteristics of sample after treatment by coagulation-flocculation are presented in Table 7.

Table 7. Physico-chemical characteristics of the sample after treatment by coagulation-flocculation. 


\begin{tabular}{|c|c|}
\hline Parameters & Sample \\
\hline Conductivity $\left(\mu \mathrm{S} \mathrm{cm}^{-1}\right)$ & 8400.00 \\
\hline Salinity $\left(\mathrm{mg} \mathrm{L}^{-1}\right)$ & 6371.80 \\
\hline $\mathrm{pH}$ & 7.12 \\
\hline Turbidity (NTU) & 0.28 \\
\hline$\left[\mathrm{Ca}^{2+}\right]\left(\mathrm{mg} \mathrm{L}^{-1}\right)$ & 168.00 \\
\hline$\left[\mathrm{Mg}^{2+}\right]\left(\mathrm{mg} \mathrm{L}^{-1}\right)$ & 272.16 \\
\hline$[\mathrm{F}]\left(\mathrm{mg} \mathrm{L}^{-1}\right)$ & 1.42 \\
\hline
\end{tabular}

From (Table 6 and Table 7), it is necessary to mention that coagulation process can remove fluoride and suspended particles. Furthermore we observe a slight decreasing of the hardness and a slight increasing of the salinity of the brackish water.

Optimum conditions and residual fluoride concentrations for synthetic and sample water containing fluoride are summarized in (Table 8).

Table 8. Fluoride removal at optimum conditions for synthetic and natural water containing fluoride.

\begin{tabular}{|l|c|c|c|c|c|c|}
\hline \multicolumn{1}{|c|}{ Sample } & $\begin{array}{c}{[\mathrm{F}]_{0}} \\
\left(\mathrm{mg} \mathrm{L}^{-1}\right)\end{array}$ & $\begin{array}{c}{\left[\mathrm{Al}^{3+}\right]_{\text {opt. }}} \\
\left(\mathrm{mg} \mathrm{L}^{-1}\right)\end{array}$ & $\begin{array}{c}{\left[\mathrm{MgCl}_{2} \cdot 6 \mathrm{H}_{2} \mathrm{O}\right]_{\text {opt. }}} \\
\left(\mathrm{mg} \mathrm{L}^{-1}\right)\end{array}$ & $\begin{array}{c}{[\mathrm{FABI}]} \\
\left(\mathrm{mg} \mathrm{L}^{-1}\right)\end{array}$ & $\begin{array}{c}\text { Settling } \\
\text { time }(\mathbf{m i n})\end{array}$ & $\begin{array}{c}{[\mathrm{F}]_{\text {res. }}} \\
\left(\mathrm{mg} \mathrm{L}^{-1}\right)\end{array}$ \\
\hline Synthetic water & 3.00 & 8 & 200 & 4.20 & 60 & 1.34 \\
\hline Natural water & 3.42 & 8 & 200 & 4.20 & 60 & 1.42 \\
\hline
\end{tabular}

Under optimal parameters residual fluoride concentration achieves $1.42 \mathrm{mg} \mathrm{L}^{-1}$ corresponding to a removal efficiency up to $59 \%$. In sum, aluminum is a suitable coagulant for fluoride removal. Moreover, the fixed level of fluoride in drinking water recommended by WHO is reached $\left(1.50 \mathrm{mg} \mathrm{L}^{-1}\right)$.

\section{Conclusion}

In this study coagulation process with alum was applied in the treatment of water containing fluoride. Experimental results showed that the effect of initial $\mathrm{pH}$ of solution of residual fluoride concentration is negligible and optimal $\mathrm{pH}$ was fixed at $\mathrm{pH}=7$. High fluoride concentration is disadvantageous for fluoride removal. Coagulant dose was optimized for the different studied fluoride concentrations. Residual fluoride concentration decreases with the increasing of coagulation adjuvant dose, subsequently optimal dose was determined for the different studied fluoride concentrations. The effect of commercial flocculent (FABI) and settling time were studied, residual fluoride concentration and residual turbidity were evaluated. Optimal flocculent dose and optimal settling time were $4.2 \mathrm{mg} \mathrm{L}^{-1}$ and 60 min respectively.

The statistical analysis of experimental design methodology showed that initial fluoride concentration, coagulant dose, adjuvant dose and settling time had a considerable effect on fluoride removal by coagulation-flocculation. Precisely, initial fluoride concentration has a positive effect unlike coagulant dose, coagulation adjuvant dose and settling time.

Coagulation tests were performed to evaluate the efficiency of coagulation-flocculation process for south Tunisian brackish water with high fluoride concentration. The obtained results showed that, under optimal parameters, residual fluoride concentration achieves $1.42 \mathrm{mg} \mathrm{L}^{-1}$ corresponding to a removal efficiency of $59 \%$. So it can be concluded that when coagulation-flocculation process is used for fluoride removal from brackish water, it is possible to reach the limit recommended by $\mathrm{WHO}$ for fluoride concentration in drinking water, $1.5 \mathrm{mg} \mathrm{L}^{-1}$. Accordingly this water could be drinkable if the content of the residual aluminum rate is below the limit recommended by WHO $\left(0.02 \mathrm{mg} \mathrm{L}^{-1}\right)$.

\section{REFERENCES}

[1] Rodier, J., 1997. "L’analyse de l'eau", 8ème édition, DUNOD, Paris.

[2] Pontié, M., Schrotter, J., Lhassani, C. A., Diawara, C. K., 2006. Traitement des eaux destinées à la consommation humaine, Elimination domestique et industrielle du fluor en excès, Fluor et Environnement, L'actualité chimique - $\mathrm{N}^{\circ}$ 301-302, 2-7. 
[3] W., Gonga, Qua, J., Liua, R., Lana, H., 2012. Effect of aluminum fluoride complexation on fluoride removal by coagulation, Colloids and Surfaces A: Physicochem. Eng. Aspects 395, 88-93.

[4] Mouna, B., 2005. Cartes de fluor et de fluorose en Tunisie, Thèse en médicine dentaire, Monastir, Tunisie.

[5] AFSSA, 2004. Évaluation des risques sanitaires liés aux situations de dépassement des limites et références de qualité des eaux destinées à la consommation humaine, Paris, 96.

[6] J. Zhu, H. Zhao, J. Ni, 2007, Fluoride distribution in electrocoagulation defluoridation process, Sep. Purif. Technol. 56, 184-191.

[7] Mjengera, H., Mkongo, G., 2004. Appropriate deflouridation technology for use in flourotic areas in Tanzania, Phys. Chem. Earth 26, 1097.

[8] Shen, F., Chen, X., Gao, P., Chen, G., 2003. Electrochemical removal of fluoride ions from industrial wastewater, Chem Eng. Sci. 58, 987.

[9] Rossini, M., Garcia Garrido, J., Galluzzo, M., 1999. Optimization of the coagulation-flocculation treatment: influence of rapid mix parameters, Water Research $33 \mathrm{~N}^{\circ} 8,1817-1826$.

[10] Hu, C., Liu, H., Chen, G., Qu, J., 2012. Effect of aluminum speciation on arsenic removal during coagulation process, Sep. Purif. Technol. 86, 35-40.

[11] Duan, J., Gregory, J., 2003. Coagulation by hydrolysing metal salts, Adv. Colloid Interface Sci. 100-102, 475-502.

[12] Verma, A. K., Dash, R. R., Bhunia, P., 2012. A review on chemical coagulation/flocculation technologies for removal of colour from textile wastewaters, J. Environ Manage. 93, 154-168.

[13] Masschelein, W. J., 1999. Processus unitaires du traitement de l'eau potable, Ed CEBEDOC.

[14] Behbahani,M., Alavi Moghaddam, M. R., Arami, M., 2011. Techno-economical evaluation of fluoride removal by electrocoagulation process: Optimization through response surface methodology, Desalination 271, $209-218$.

[15] Youcef, L., Achour,S., 2001. Defluoruration des eaux souterraines du sud algérien par la chaux et le sulfate d'aluminium, Courrier du Savoir Scientifique et Technique Nº1: 65-71.

[16] Nieboer, E., Gibson, B.L., Oxman, A.D., Kramer, J. R., 1995. Health effects of aluminum : a critical review with emphasis on aluminum in drinking water Environ. Reviews 3, 29-81.

[17] Zhang, G., Gao,Y., Zhang,Y., Gu, P. 2005. Removal of fluoride from drinking water by a membrane coagulation reactor (MCR), Desalination 177, 143-155.

[18] Goupy, J. 1996. "Techniques de l'ingénieur, La méthode des plans d'expériences", DUNOD, Paris.

[19] Haaland, D. P. 1989. "Experimental Design in Biotechnology" Marcel Dekker Inc. New York. 